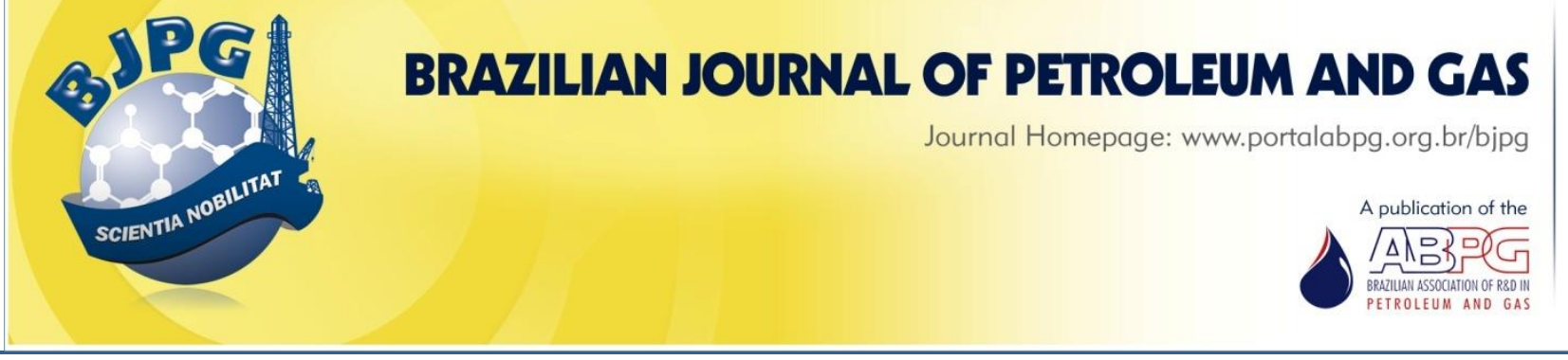

\title{
STUDY OF NEW ALTERNATIVES FOR REMOVAL OF SULFUR FROM DIESEL
}

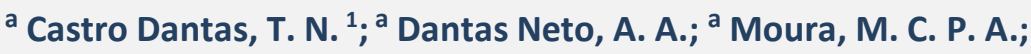 \\ ${ }^{a}$ Barros Neto, E. L.; ${ }^{a}$ Forte Duarte, K. R. \\ a Universidade Federal do Rio Grande do Norte, Departamento de Engenharia Química, Natal-RN, Brazil
}

\begin{abstract}
This work aims to develop new methods of removing sulfur from commercial diesel using surfactants and microemulsion systems. Its main purpose is to propose new technologies and add economic viability to the process. First, for the choice of the surfactant, a preliminary study was made using an extraction formulation based on a Winsor-I microemulsion system formed with either dodecyl ammonium chloride (DDAC) or ethoxylated nonylphenol (RNX95) as surfactant. It was verified that RNX95 was the best surfactant to be used in microemulsion systems to modify adsorbent surfaces, and as extracting agents in liquid-liquid extraction operations. Vermiculite treated with a microemulsion system was used as adsorbent. The microemulsion system used in the modification of the vermiculite surface was composed of RNX95 (surfactant), butan-1-ol (cosurfactant), n-hexane (oil phase), and distilled water (aqueous phase). Batch adsorption tests were carried out to assess the ability of vermiculite to adsorb sulfur from diesel. The experiments were performed according to a factorial design $\left(2^{3}\right)$ evaluating the effects of temperature, concentration of $\mathrm{CaCl}_{2}$ in the aqueous phase, and vermiculite granule size. The best result was obtained at $60^{\circ} \mathrm{C}, 1500-\mathrm{ppm} \mathrm{CaCl} 2$ aqueous solution, and $-48+65$ mesh vermiculite particle size. Under such conditions, the vermiculite adsorbed $4.24 \mathrm{mg}$ of sulfur/g of adsorbent, corresponding to $68.7 \%$ sulfur removal. Twoand six-stage liquid-liquid extraction experiments were performed using the same surfactant-to-diesel ratio. The process yielded $46.8 \%$ sulfur removal in the two-stage experiment, and $73.15 \%$ in the six-stage one. An alternative study, for comparison purposes, was made using bentonite and diatomite as adsorbents. The batch experiments were done using microemulsion systems with the same aqueous phases used in the vermiculite study, with $20-\mathrm{ppm}$ and $1500-\mathrm{ppm} \mathrm{BaCl}{ }_{2}$ solutions. With bentonite, the best adsorption capacity was $7.53 \mathrm{mg}$ sulfur/g adsorbent with distilled water as aqueous phase of the microemulsion system, and with diatomite the best result was $17.04 \mathrm{mg}$ sulfur/g adsorbent using a 20ppm $\mathrm{CaCl}_{2}$ solution.
\end{abstract}

\section{KEYWORDS}

diesel; sulfur removal; adsorption; vermiculite; surfactant; microemulsion

\footnotetext{
${ }^{1}$ To whom all correspondence should be addressed.

Address: Universidade Federal do Rio Grande do Norte, Centro de Tecnologia/PPGEQ, Campus Universitário, Natal, RN - Brazil, Zip code: 59072-970 | Telephone/Fax number: +55 84 3215-3773/ +55 84 3215-3827| e-mail: tereza@eq.ufrn.br doi:10.5419/bjpg2014-0002
} 


\section{INTRODUCTION}

Petroleum has been part of human life since ancient times. It comprises hydrocarbons as the main constituents, in addition to small amounts of sulfur, nitrogen, oxygen, and trace metals. Diesel, among others, is one of the petroleum-derived fuels. Petroleum-derived diesel consists of a mixture of around $75 \%$ saturated hydrocarbons and $25 \%$ aromatic hydrocarbons. Sulfur is the main contaminant of diesel fuel and is present in a concentration that ranges between 0.1 and $0.5 \%$. It is undesirable for the environment and engines because sulfur increases the polarity of diesel, increasing the stability of emulsions. It also enhances corrosion, poisons catalysts, and confers color and odor to final products. Sulfur oxides formed by diesel combustion can be discharged into the atmosphere as particulates or as gaseous pollutants, such as $\mathrm{SO}_{2}$ and $\mathrm{SO}_{3}$, causing great damage to the environment and to human health.

The international concern for a clean and healthy environment has led to the establishment of more restrictive laws and regulations regarding emissions of pollutants in the air, with the proposal of increasingly low sulfur levels in fuels. Due to these recent changes in regulations, additional refining of diesel is essential to remove sulfur, which contributes to higher fuel costs. In recent years, many researches for advanced technologies seeking to obtain economically viable and efficient alternatives to remove sulfur from petroleumderived fuels have been developed (Braun et al., 2003; Thomas, 2001).

The concentrations of many sulfur compounds, in addition to other petroleum contaminants, have been continuously reduced in refineries using various treatments and separation processes aiming to improve the quality of the final products. For sulfur removal, two processes can be used: a gas sweetening process, which aims to transform aggressive sulfur compounds $\left(\mathrm{S}, \mathrm{H}_{2} \mathrm{~S}, \mathrm{R}-\mathrm{SH}\right)$ into other less harmful products (RSSR-disulfides) without removing them from the final product; and a desulfurization process, which effectively removes sulfur compounds.

Desulfurization is a process used for the effective removal of sulfur from fuels, although with high costs to refineries. This cost is particularly very high with diesel samples from Brazilian oil fields, because of the large amounts of sulfur present in them. The more traditional process involves hydrodesulfurization (HDS), which is based on the elimination of contaminants by hydrogenation reactions. The disadvantages of this process include the need of high investments in facilities, application of extreme temperatures $\left(200\right.$ to $425^{\circ} \mathrm{C}$ ) and pressures (150 to $250 \mathrm{psi}$ ) in the process, and the use of a sophisticated catalysts consisting for example of a basic material impregnated with cobalt and molybdenum (Izumi et al., 1994; Mochida, 1996). Hydrodesulfurization is inefficient in removing some sulfur compounds, such as heterocyclic dibenzothiophenes (DBT) and alkylsubstituted dibenzothiophenes (DBTS) (Knudsen et al., 1999).

Adsorption processes can also be used to extract sulfur compounds from petroleum-derived fuels. They can be subdivided according to the interaction mechanism between the sulfur compound and the adsorbent. Adsorptive desulfurization is based on the physical adsorption of sulfur compounds on the surface of a solid adsorbent. Desulfurization by reactive adsorption involves the chemical interaction between the adsorbent and the sulfur compounds. Once the phenomenon stops, the adsorbent can be regenerated by eliminating $\mathrm{H}_{2} \mathrm{~S}, \mathrm{~S}$, or $\mathrm{SO}_{\mathrm{x}}$, depending on the applied process. The efficiency of the method is defined by the adsorbent properties, including: adsorption capacity, selectivity for sulfur compounds, durability, and regeneration of spent adsorbent (Babich \& Moulijn, 2003).

Surfactants are amphiphilic molecules that cause variations in interfacial tensions. They have at least two interlinked parts on the same molecule: one polar or hydrophilic, and another nonpolar or hydrophobic. However, these moieties are spaced enough to behave independently. The hydrophilic part is referred to as the headgroup, and the hydrophobic part as the tail (Santos et al, 2009; del Nunzio, 1980; Attwood \& Florence, 1983).

Microemulsions $(\mu \mathrm{E})$ are dispersed systems formed by the spontaneous solubilization of two otherwise immiscible liquids, in the presence of surfactants, with or without the aid of a cosurfactant. Microemulsion systems are thermodynamically stable, macroscopically homogeneous and optically transparent, and present low viscosity, low interfacial tension, and 
high capacity to solubilize contaminants (Clause et al., 1987; Prince, 1977; Scriven, 1982).

Winsor (1948) classified the multiphase systems containing microemulsions in four different types of phase equilibrium. Macroscopically, a single-phase microemulsion system is called Winsor IV (WIV). Winsor I (WI) and Winsor II (WII) refer to two-phase systems, where the microemulsion system is in equilibrium with excess oil (WI) and aqueous (WII) phases, respectively. The three-phase system, called Winsor III (WIII), occurs when the microemulsion is in equilibrium with both the excess aqueous and oil phases.

Many solids are able to adsorb gases and liquids. However, only a few can be classified as commercial adsorbents, requiring favorable characteristics, such as efficiency, selectivity, mechanical resistance, low pressure drop, low cost, low agglomeration capacity, chemical inertness, and especially large interfacial area (Gomide, 1988). According to Sari and Tuzen (2013), vermiculite is ubiquitous in nature, can be easily acquired and is an inexpensive material that features a stable negative charge, large surface area, and numerous highly-reactive surface sites. These advantageous characteristics render it a suitable adsorbent for many purposes.

Vermiculite is a typical clay mineral that has the highest cation-exchange capacity among clay minerals. It is a naturally occurring phyllosilicate mineral, consisting of silicon, aluminum, iron, magnesium and water in varying proportions. It has a 2:1 layered structure, meaning two tetrahedral sheets with an octahedral sheet in between. The tetrahedral layers are formed by tetrahedral silicon $\left(\mathrm{SiO}_{2}\right)$ that can be isomorphically replaced with trivalent aluminum $\left(\mathrm{Si}^{+4} \rightarrow \mathrm{Al}^{+3}\right)$. Interlayer cations and water molecules separate the vermiculite layers. Vermiculite also presents a particularity unique ability in relation to other micas: when it is heated at $800-1000^{\circ} \mathrm{C}$, the interlayer water transforms into steam producing an exfoliation material, which expands to 10 to 30 times the initial volume (Grim, 1968; Rau, 1985). The tetrahedral and octahedral sheets have a negative charge as a result of isomorphic substitutions (Padilla-Ortega et al., 2014; Santos, 1989; Turan \& Ozgonenel, 2013; Valdiviezo et al., 2003).

Many studies address desulfurization of petroleum derivatives. However, there is still much to be explored since environmental legislation imposes increasingly lower sulfur contents in fossil fuels. Hernandez-Maldonado et al. (2004) studied the desulfurization of a commercial diesel, in a fixed-bed apparatus, at ambient temperature and pressure, using $\mathrm{Ni}(\mathrm{II})-\mathrm{Y}$ and $\mathrm{Ni}(\mathrm{II})-\mathrm{X}$ zeolites. The results obtained by these authors showed that $\mathrm{Ni}(\mathrm{II})$-exchanged zeolites are superior adsorbents for the removal of sulfur compounds from commercial diesel fuels.

Scherer et al. (2009) studied the desulfurization of a commercial diesel doped with benzothiophene and dibenzothiophene $(1000 \mathrm{~g})$ by an adsorption process using three types of activated alumina (acidic, basic, and neutral forms) as adsorbent materials. For comparison purposes, the adsorption process was also carried out using oxidized diesel samples. Hydrogen peroxide $\left(\mathrm{H}_{2} \mathrm{O}_{2} 30 \%\right)$ and acetic acid were used as oxidizing agents. They observed that the application of alumina in the adsorption process is a promising alternative for the removal of sulfur compounds, being more selective with benzothiophene than with dibenzothiophene. The authors detected that dibenzothiophene removal is more effective in non-oxidized samples, whereas benzothiophene is almost totally removed in oxidized samples. The contact time affects the adsorption process, reaching $80 \%$ of dibenzothiophene removal after 12 hours.

Drangan and Butucea (2012) studied the adsorption equilibrium of $\mathrm{SO}_{2}$ in Y-zeolites ( $\mathrm{HY}$ and $\mathrm{NaY}$ ). The adsorption isotherms of sulfur dioxide in the zeolites used were determined experimentally at three temperatures $\left(25,50\right.$, and $\left.100^{\circ} \mathrm{C}\right)$. The results were adjusted to the Langmuir and Freundlich theoretical models. The authors concluded that the studied zeolites are good adsorbents and their adsorption capacities decreased with increasing temperature. The Freundlich model was better fitted to the experimental data, and the $\mathrm{NaY}$ zeolite presented greater adsorption capacity than the HY one.

Al Zubaidy et al. (2013) used adsorption as a desulfurization method for commercial diesel containing $410 \mathrm{ppm}$ of sulfur. These authors used commercial activated carbon and carbonized date palm kernel powder as adsorbents. The experiments were performed in batch at room temperature. Activated carbon reduced the sulfur content from $410 \mathrm{ppm}$ to $251 \mathrm{ppm}$ when $5 \mathrm{wt} . \%$ of adsorbent was used, and to $184.6 \mathrm{ppm}$ when $10 \mathrm{wt} . \%$ 
Table 1. Specifications of diesel oil (A-S1800)*.

\begin{tabular}{lcc}
\hline \multicolumn{1}{c}{ Propriety } & Method & Result \\
\hline Aspect (visual) & D 4176 & Clear and free of impurities \\
Color (visual) & VIS 000 & From yellow to orange \\
Total sulfur $(\mathrm{ppm})$ & D 4294 & 1233.00 \\
Specific gravity at $20^{\circ} \mathrm{C}\left(\mathrm{kg} / \mathrm{m}^{3}\right)$ & D 4052 & 834.4 \\
Viscosity at $40^{\circ} \mathrm{C}\left(\mathrm{mm}^{2} / \mathrm{s}\right)$ & D 445 & 3.47 \\
Cold filter plugging point $(\mathrm{CFPP})\left({ }^{\circ} \mathrm{C}\right)$ & D 6371 & 14 \\
Water and sediment $(\%$ volume) & D 2709 & 0 \\
Ash (\% mass) & D 482 & $<0.0010$ \\
Ramsbottom Carbon Residue of Petroleum on $10 \%$ & D 524 & 0.11 \\
(v/v) distillation residues $(\% m a s s)$ & D 4737 & 52.5 \\
Calculated cetane number & D 93 & 38 \\
Flashpoint $\left({ }^{\circ} \mathrm{C}\right)$ & D 2624 & 89 \\
Electrical conductivity at $28^{\circ} \mathrm{C}(\mathrm{pS} / \mathrm{m})$ & & \\
\hline
\end{tabular}

* Diesel fuel with an $1800 \mathrm{mg} / \mathrm{kg}$ maximum sulfur limit.

of adsorbent was used. Carbonized date palm kernel powder showed an inferior performance, considering that $6 \mathrm{wt} . \%$ of adsorbent was used to yield only $34.15 \%$ in sulfur reduction.

The objective of this work is therefore to investigate novel alternatives for sulfur removal by surfactants and microemulsion systems using adsorption and liquid-liquid extraction processes. The investigation focuses on the use of a microemulsion system to modify the surface of adsorbents, especially vermiculite. The experimental data obtained with these modifiedvermiculite systems will be compared with those acquired with other adsorbents, also modified by the same microemulsion.

\section{MATERIALS AND METHODS}

\subsection{Materials}

Reagents used during the experiments were of analytical grade, $99 \%$ purity, except diesel, supplied by Petrobras, with the physical-chemical properties listed in Table 1.

Dodecyl ammonium chloride (DDAC) and ethoxylated nonylphenol (RNX95) were employed as surfactants. The cationic surfactant DDAC was synthesized in laboratory by dilution of dodecylamine in ethanol and hydrochloric acid (5\%), as described by Teixeira (2004). Commercial ethoxylated nonylphenol (RNX95), a nonionic surfactant, was used without further purification. With a hydrophilic-lipophilic balance of 13 , its headgroup contains approximately 9 to 10 ethylene oxide molecules, which enhances the solubility characteristics and increases the cloud point.

Vermiculite, from Santa Luzia (PB, Brazil), was the adsorbent selected for this research. It was acquired in its raw form and subsequently treated to obtain its sodium form before being modified by the microemulsion. Adsorption tests were carried out in a batch with bentonite and diatomite as adsorbents, all without previous treatments, however modified by the microemulsion systems. This step aimed to promote an alternative study, comparing the vermiculite with other adsorbents.

\subsection{Microemulsion systems}

Table 2 presents the constituents of microemulsion systems prepared during the experimental procedures. The research began with the identification of the Winsor regions in a pseudoternary diagram. The tests were conducted at room temperature $\left(25^{\circ} \mathrm{C}\right)$. First, $1 \mathrm{~g}$ of a mixture of surfactant (S) and cosurfactant (C) at a C/S mass ratio equal to 1.0 was added in test tubes to either $1 \mathrm{~g}$ of the aqueous phase or $1 \mathrm{~g}$ of the oil phase, and then these solutions were titrated with oil phase or aqueous phase, respectively. The transitions from one region to another were identified upon formation or disappearance of turbidity, after the dropwise addition of the titrating solution. When 
Table 2. Constituents of the microemulsion systems prepared in this study.

\begin{tabular}{cccccc}
\hline System & Surfactant (S) & Cosurfactant (C) & Oil phase (OP) & Aqueous phase (AP) & C/S ratio \\
\hline 1 & DDAC & Butan-1-ol & n-Hexane & Distilled water & 1 \\
2 & RNX95 & Butan-1-ol & n-Hexane & Distilled water & 1 \\
3 & RNX95 & Butan-1-ol & n-Hexane & 20-ppm CaCl 2 aqueous solution & 1 \\
4 & RNX95 & Butan-1-ol & n-Hexane & 1500-ppm CaCl 2 aqueous solution & 1 \\
\hline
\end{tabular}

turbidity was observed, the system was weighed and the titration process continued until the formation of another phase. When the formation of a new phase was not observed, the titration process continued until exceeding half of the total volume of the test tube to make sure that the system remained in the same region.

\subsection{Choice of surfactant for sulfur removal}

Experiments in the Winsor I domain were performed to define the surfactant used for application in sulfur removal processes. The Winsor I experimental point was composed by (\% mass): $10 \%$ AP (distilled water), 20\% C/S (butan-1-ol / DDAC or butan-1-ol / RNX95), and 70\% OP (diesel). The constituents were mixed and then stirred for 30 minutes at $1200 \mathrm{rpm}$. After stirring, the mixture was centrifuged for 5 minutes at $3800 \mathrm{rpm}$, and the upper oil phase was removed with the aid of a syringe for sulfur content analysis (ANTEK Analyzer 9000, NS model).

\subsection{Purification of vermiculite and generation of the $\mathrm{Na}$ form}

Initially, raw vermiculite (as received) was washed out several times with deionized water, until the water came out clear. The material was dried in an oven at $40^{\circ} \mathrm{C}$ during 2 days. Then, in a 2L glass beaker, $200 \mathrm{~g}$ of this treated vermiculite were placed in contact with a sodium acetate buffer solution $(\mathrm{pH} \mathrm{5)}$, in order to double the volume occupied by the clay. The mixture was kept under stirring (1200rpm), adjusting the temperature to $40^{\circ} \mathrm{C}$. After temperature stabilization, $120 \mathrm{~mL}$ of hydrogen peroxide solution $\left(\mathrm{H}_{2} \mathrm{O}_{2}\right)$ were added, keeping these conditions of temperature and stirring for 3 days. At the end of this process, the excess solution was removed and the clay was washed out several times with deionized water, until removing all acetate odor and the water became clear. The material was dried again using the same procedure. To obtain the Na-vermiculite, a 1-M NaCl solution was added to the dry clay at the same proportion used for the sodium acetate buffer solution. The mixture remained under stirring (1200rpm) during $7 \mathrm{~h}$, at $40^{\circ} \mathrm{C}$. This procedure was repeated two more times. Finally, the sodium clay was washed out with abundant deionized water and was dried in an oven at $40^{\circ} \mathrm{C}$ during 2 days (Almeida, 2008).

\subsection{Vermiculite characterization}

The grain-size analyses of the $\mathrm{Na}$-vermiculite $(500 \mathrm{~g})$ were made in a set of six sieves $(8,20,35,48$, 65 , and 100 mesh) placed in a mechanical shaker (Bertel, BTL000), for $10 \mathrm{~min}$. After stirring, the weight of each sieve was measured. Scanning electronic microscopy (SEM) images were recorded using a Shimadzu (EPMA 1720H) microscope. The samples were deposited on Al stubs using a doublefaced tape. Then, the samples were coated with gold to ensure conductivity and to generate images with good resolution. The chamber pressure was around 0.1 to $0.05 \mathrm{mbar}$. The Al stubs were bombarded with inert argon gas.

\subsection{Surface modification of adsorbents}

The micoemulsion used for the modification of adsorbent surfaces was composed by (\% mass): $35 \%$ butan-1-ol / RNX95 (C/S = 1), 2\% distilled water, and $63 \% \mathrm{n}$-hexane. The adsorbents were prepared by adding $5 \mathrm{~g}$ of adsorbent to a glass plate and $10 \mathrm{~mL}$ of microemulsion to wet the adsorbent completely. Then, the samples were dried in an oven at $60^{\circ} \mathrm{C}$. The drying time varied between $24,36,48,60$, and 72 hours to determine the effect of this parameter. The samples were weighed before and after drying to determine the amount of material retained in the adsorbent's surface. All assays were done in duplicate. 
Table 3. Levels assumed by independent factors evaluated in sulfur adsorption by vermiculite.

\begin{tabular}{|c|c|}
\hline Factors & Levels \\
\hline Temperature $\left({ }^{\circ} \mathrm{C}\right)$ & 25 (min.) and 60 (max.) \\
\hline \multicolumn{2}{|c|}{$\mathrm{CaCl}_{2}$ concentration in the aqueous phase (ppm) $20 \mathrm{ppm}$ (min.) and1500 ppm (max.) } \\
\hline Grain size & $-48+65$ (min.) and $-65+100$ (max.) \\
\hline
\end{tabular}

Table 4. Composition of microemulsion systems used in the impregnation of vermiculite, diatomite and bentonite surfaces.

\begin{tabular}{cccccc}
\hline System & Surfactant (T) & Cosurfactant (C) & Oil phase (OP) & Aqueous phase (AP) & C/S ratio \\
\hline 1 & RNX95 & Butan-1-ol & n-Hexane & Distilled water & 1 \\
2 & RNX95 & Butan-1-ol & n-Hexane & 20-ppm CaCl 2 aqueous solution & 1 \\
3 & RNX95 & Butan-1-ol & n-Hexane & 1500-ppm CaCl aqueous solution & 1 \\
4 & RNX95 & Butan-1-ol & n-Hexane & 20-ppm BaCl 2 aqueous solution & 1 \\
5 & RNX95 & Butan-1-ol & n-Hexane & 1500-ppm BaCl 2 aqueous solution & 1 \\
\hline
\end{tabular}

\subsection{Batch adsorption experiments for sulfur removal}

Batch experiments were conducted by adding $10 \mathrm{~g}$ of adsorbent (previously impregnated with the microemulsion) and $50 \mathrm{~mL}$ of diesel to $125-\mathrm{mL}$ stoppered Erlenmeyer flasks. The formulations were mixed using a thermostatic shaker, at $60^{\circ} \mathrm{C}$ and $1200 \mathrm{rpm}$. Afterwards, according to a determined contact time ( $1 \mathrm{~h}, 2 \mathrm{~h}, 4 \mathrm{~h}, 6 \mathrm{~h}, 18 \mathrm{~h}$, and $24 \mathrm{~h}$ ), $1.5-\mathrm{mL}$ aliquots were withdrawn with the aid of a syringe and the sulfur concentration was determined. The initial and equilibrium concentrations of sulfur were determined using an ANTEK Analyzer. The adsorption capacity $(q)$ was determined using Eq. 1:

$$
q=V \frac{\left(C_{0}-C_{E}\right)}{M_{a d s}}
$$

Where $C_{O}$ and $C_{E}$ are the initial and final (equilibrium) concentrations of sulfur in diesel ( $\left.\mathrm{mg} . \mathrm{mL}^{-1}\right)$, respectively; $V$ is the diesel volume $(\mathrm{mL})$; and $M_{\text {ads }}$ is the mass of adsorbent (g) used in the experiment.

\subsection{Optimization of the adsorption parameters for microemulsion- modified vermiculite}

This work used a $2^{3}$ factorial planning, i.e., three factors were studied and each one was observed in two levels (maximum and minimum), resulting in 8 experimental runs. To estimate the experimental error, the tests were made in duplicate. The experiments were performed in batch, with $18 \mathrm{~h}$ of contact time, 1:5 adsorbent/diesel ratio, and in random order, to prevent undesirable factors. The selected factors were temperature, salt concentration in the aqueous phase, and grain size of the adsorbent. The levels evaluated for each factor are shown in Table 3.

\subsection{Adsorption isotherms}

The assays to obtain the adsorption isotherms were carried out in batch using stoppered $125-\mathrm{mL}$ Erlenmeyer flasks. A fixed diesel volume $(5 \mathrm{~mL})$, with a known sulfur initial concentration of $1233 \mathrm{ppm}$, was added to seven samples of microemulsionmodified vermiculite, with varied masses. The mixtures were placed in a thermostatic shaker, at $60^{\circ} \mathrm{C}$ and $1200 \mathrm{rpm}$. After $24 \mathrm{~h}$ of contact time, the samples were filtered and $1.5 \mathrm{~mL}$ was used for determining the sulfur concentration. The isotherms were constructed by plotting the amount of adsorbate on the adsorbent $\left(q_{e}\right.$, in $\mathrm{mg} / \mathrm{g}$ ) as a function of sulfur concentration at equilibrium $\left(C_{E}\right.$, in $\mathrm{mg} \cdot \mathrm{mL}^{-1}$ ).

\subsection{Comparative study: Modification of other adsorbents}

In view of the results obtained with vermiculite, a comparative study using bentonite and diatomite modified by microemulsion followed. The procedure for surface modification of adsorbents was the same as described for vermiculite modification. In these experiments, the solutions shown in Table 4 were tested as the aqueous phase of the microemulsion, in addition to distilled water. 
The experiments were performed in batch, using $10 \mathrm{~g}$ of adsorbent and $50 \mathrm{~mL}$ of diesel. Afterwards, according to a fixed contact time $(1 \mathrm{~h}, 2 \mathrm{~h}, 4 \mathrm{~h}, 6 \mathrm{~h}$, $18 \mathrm{~h}$, and $24 \mathrm{~h}$ ), $1.5-\mathrm{mL}$ aliquots were withdrawn with the aid of a syringe and the sulfur concentration was determined. The values were used to determine the load capacity of each adsorbent.

\subsection{Liquid-liquid extraction experiments}

Two- and six-stage liquid-liquid extraction experiments were carried out using RNX95 and diesel in graduated cylinders in crosscurrent operation mode. For two-stage experiments, first $25 \mathrm{~mL}$ of RNX95 were added to $25 \mathrm{~mL}$ of diesel. The mixture was stirred for $30 \mathrm{~min}$ and then centrifuged for $5 \mathrm{~min}$ at 3800rpm. Then, it was separated and an aliquot of diesel was used to determine the sulfur content. The second stage used $13 \mathrm{~mL}$ of the remaining diesel and an equal amount of surfactant. The stirring/centrifugation process was repeated and, again, an aliquot of diesel was used to determine the sulfur content. The second experiment, performed in six stages, used the same procedures, starting from an initial volume of $25 \mathrm{~mL}$ of diesel and $25 \mathrm{~mL}$ of RNX95.
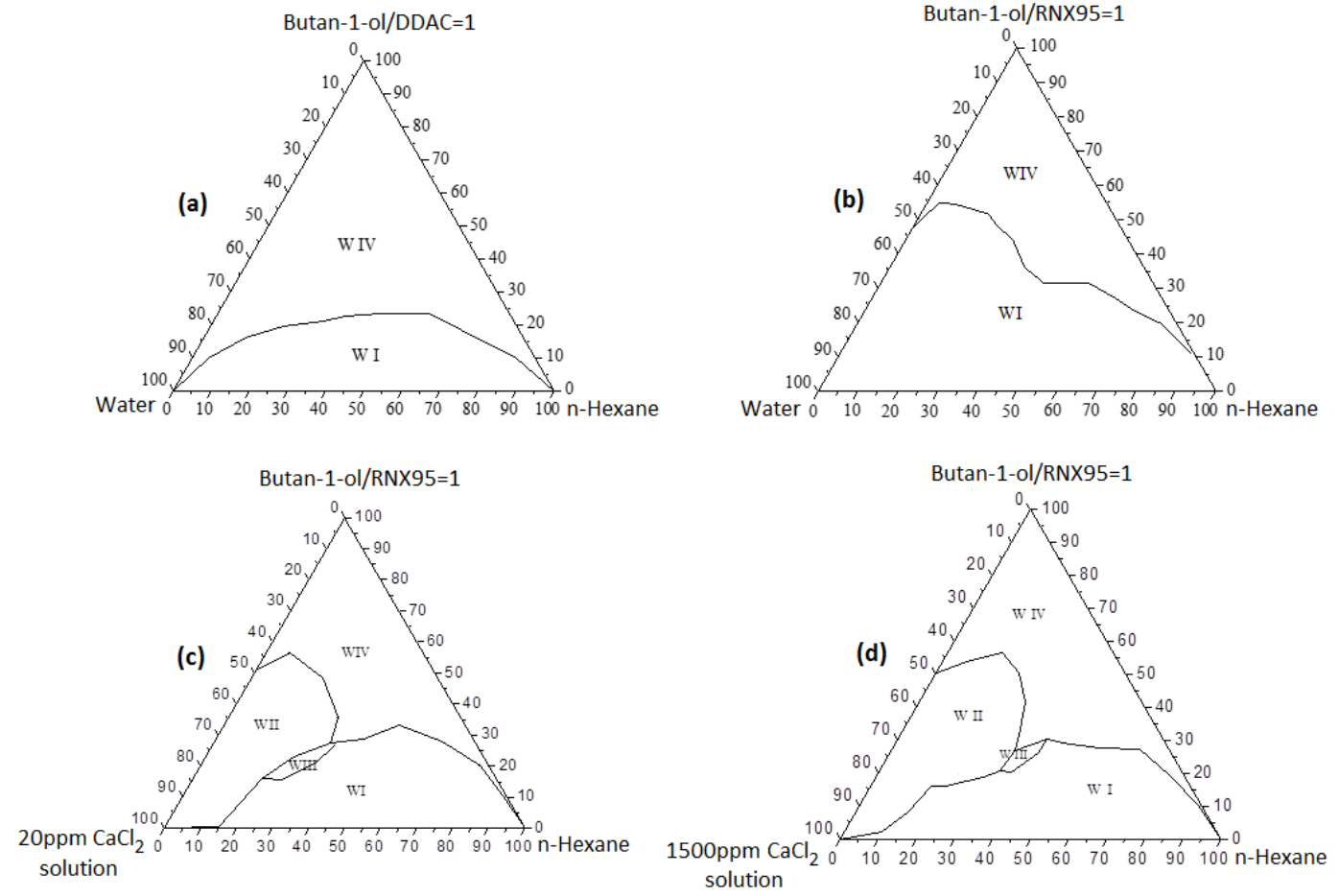

Figure 1. Pseudoternary phase diagrams showing Winsor areas: (a) distilled water, butan-1-ol/DDAC, $n$-hexane; (b) distilled water, butan-1-ol/RNX95, n-hexane; (c) 20-ppm CaCl 2 solution, butan-1-ol/RNX 95, n-hexane; (d) 1500ppm $\mathrm{CaCl}_{2}$ solution, butan-1-ol/RNX95, n-hexane.

\section{RESULTS AND DISCUSSION}

\subsection{Microemulsion systems}

Figure 1 shows the pseudoterny phase diagrams for the studied systems. Figure 1(a) shows the diagram for the system composed by DDAC, distilled water, butan-1-ol and n-hexane. Figures 1(b), 1(c) and 1 (d) represent the systems using RNX95, nhexane, butan-1-ol, and different aqueous phases (distilled water, 20-ppm $\mathrm{CaCl}_{2}$ solution, and 1500ppm $\mathrm{CaCl}_{2}$ solution, respectively). A cosurfactant/surfactant mass ratio equal to 1 was used in this work because this value represents the minimal amount of cosurfactant that is required to promote the solubilization of the studied surfactants.

Figure 1 (a) shows a wide microemulsion region (WIV). In the diagrams using RNX95, Figures 1(b), $1(c)$, and $1(d)$, the microemulsion area is smaller and remains virtually invariant with the change of the aqueous phase. Thus, the preliminary tests for vermiculite surface modification indicate that a single point inside the microemulsion region that is common to all systems and contains lower amounts of active mater ( $2 \% \mathrm{AP}, 35 \% \mathrm{C} / \mathrm{S}$, and $63 \% \mathrm{OP})$ can be used in the extraction assays.

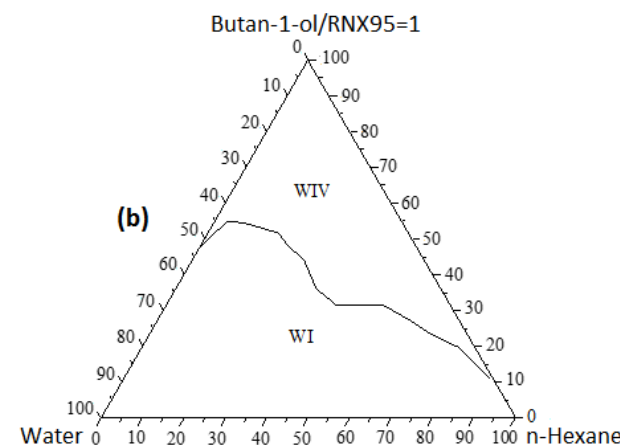


Table 5. Sulfur extraction percentage (\%E) for experiments using DDAC and RNX95 as surfactants (stirring time: $30 \mathrm{~min}$; centrifugation time: $5 \mathrm{~min}$; velocity: $3800 \mathrm{rpm}$, temperature: $30 \pm 2{ }^{\circ} \mathrm{C}$ ).

\begin{tabular}{cccc}
\hline Surfactant & $\left.{ }^{*} \mathrm{C}_{\boldsymbol{0}} / \mathbf{p p m}\right)$ & ${ }^{*} \mathrm{C}_{\mathrm{E}} / \mathbf{p p m}$ & $\% \mathrm{E}$ \\
\hline DDAC & 1233 & 1210 & 1.86 \\
RNX95 & 1233 & 1060 & 14.03 \\
\hline
\end{tabular}

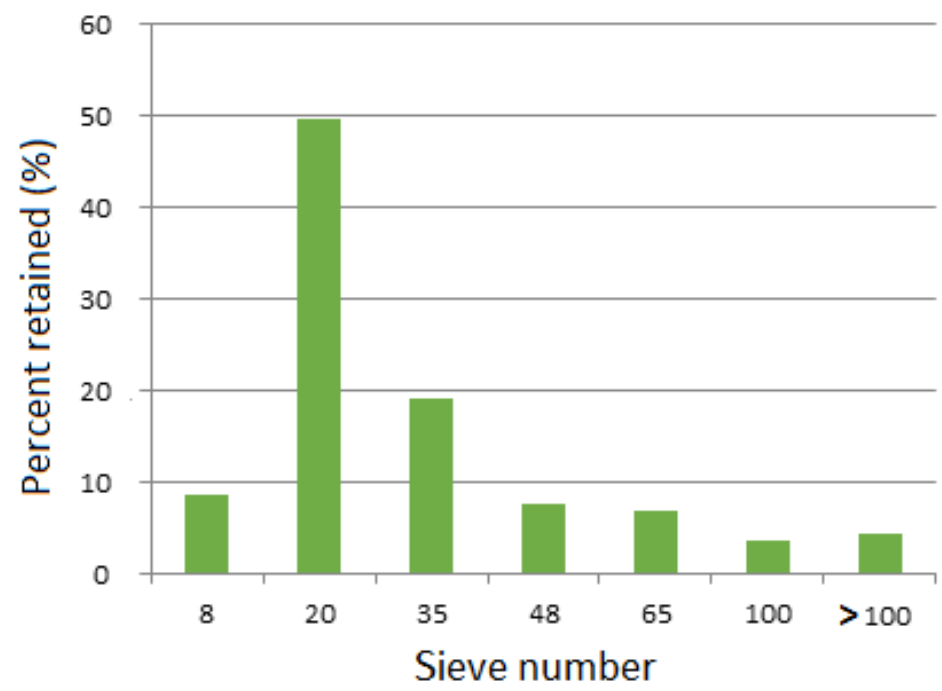

Figure 2. Grain size distribution for Na-Vermiculite.

\subsection{Choice of surfactant for sulfur removal}

For the choice of the surfactant to be used in surface modification and liquid-liquid extraction experiments, tests were carried out in the Winsor I region. The chosen point had the following composition (\% mass): $10 \%$ AP (distilled water), $20 \%$ C/S (butan-1-ol/DDAC or butan-1-ol/RNX95), and $70 \%$ OP (diesel). The results are listed in Table 5.

As one can observe in Table 5, Winsor I systems with DDAC showed an irrelevant extraction efficiency. The system with RNX95 showed a slightly improved sulfur removal. Thus, RNX95 was chosen as the surfactant to be used in the adsorption and liquid-liquid extraction experiments for sulfur removal from diesel fuel.

\subsection{Vermiculite characterization}

Figure 2 shows the distribution of particle sizes of vermiculite in Na-form. As one can observe, the highest percentage of particles was retained in $8+20$ mesh. For adsorption experiments, the $-48+65$ mesh and $-65+100$ mesh were evaluated for presenting intermediate particles sizes, which are more suitable for adsorption.
Figure 3 shows the micrographs for (a) raw vermiculite, (b) Na-vermiculite, and (c) and (d) for microemulsion-modified vermiculite. In Figures 3(a) and (b) one can observe well-defined lamellar structures. Figures $3(c)$ and (d) indicate that the lamellar structure is preserved but a surface film is formed over the sheets when treatment with microemulsion is effected.

Table 6 shows the chemical compositions of $\mathrm{Na}$ vermiculite and a microemulsion-modified vermiculite. Myers (1960) gives for vermiculite the structural formula: $(\mathrm{OH})_{2}$. $(\mathrm{Mg}, \mathrm{Fe})_{3}(\mathrm{Si}, \mathrm{Al}, \mathrm{Fe})_{4} \cdot \mathrm{O}_{10} \cdot 4 \mathrm{H}_{2} \mathrm{O}$, with silica, alumina, magnesium oxide, and iron oxides as major constituents, and $\mathrm{Ca}, \mathrm{Na}$, and $\mathrm{K}$ as common impurities. The molecular structure of the surfactant used in this research is $n-\mathrm{C}_{9} \mathrm{H}_{19}-\mathrm{C}_{6} \mathrm{H}_{4}$ $\left(\mathrm{OCH}_{2} \mathrm{CH}_{2}\right)_{\mathrm{n}} \mathrm{OH}$. Although minor modifications were detected in the composition of the two vermiculites used in this study, the major deviations were in the contents of $\mathrm{O}, \mathrm{Na}, \mathrm{Cl}$, and $\mathrm{Fe}$. The presence of $\mathrm{Ca}$ and the increase in $\mathrm{Cl}$ and $\mathrm{O}$ in the microemulsionmodified form can be attributed to ion exchange during surface modification, also confirmed by a decrease in the contents of $\mathrm{Na}$ and $\mathrm{Fe}$, as compared with the ones of the $\mathrm{Na}$ form. 

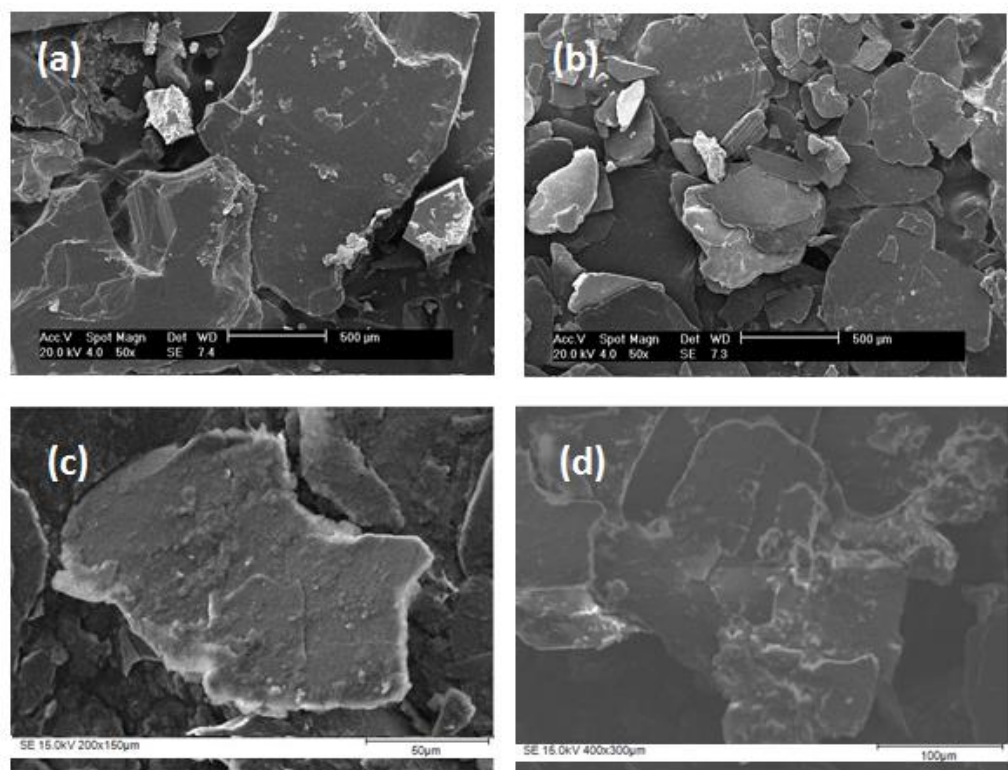

Figure 3. SEM micrographs for vermiculite: (a) raw form (50x, 20 kV); (b) Na-form (50x, 20 kV); (c) microemulsionmodified form (200x, $15 \mathrm{kV}$ ); and (d) microemulsion-modified form (400x, $15 \mathrm{kV}$ ).

Table 6. Chemical composition of Na-vermiculite and microemulsion-modified vermiculute.

\begin{tabular}{ccc}
\hline Element & Na-Form (mass \%) & $\mu \mathrm{E}-$ Form ${\text { (mass } \%)^{*}}^{*}$ \\
\hline $\mathrm{O}$ & 52.38 & 59.42 \\
$\mathrm{Na}$ & 8.85 & 4.25 \\
$\mathrm{Mg}$ & 5.46 & 7.97 \\
$\mathrm{Al}$ & 2.55 & 2.61 \\
$\mathrm{Si}$ & 22.27 & 20.68 \\
$\mathrm{Cl}$ & 0.63 & 1.62 \\
$\mathrm{~K}$ & 0.17 & - \\
$\mathrm{Ti}$ & 0.39 & - \\
$\mathrm{Fe}$ & 7.29 & 3.32 \\
$\mathrm{Ca}$ & - & 0.12 \\
Total & 100.00 & 100.00 \\
\hline
\end{tabular}

*Microemulsion with RNX95 and 1500-ppm $\mathrm{CaCl}_{2}$ solution.

\subsection{Surface modification of vermiculite: Influence of drying time}

The modification of adsorbent was made by placing $5 \mathrm{~g}$ of vermiculite in contact with $10 \mathrm{~mL}$ of microemulsion. Through a mass balance, it was possible to determine that $13 \%$ of the added microemulsion (\% mass) remained on the surface of the adsorbent. The drying temperature of the experiment was $60^{\circ} \mathrm{C}$. Considering that the microemulsion system was composed by $2 \%$ distilled water $\left(100^{\circ} \mathrm{C}\right.$ boiling point), $63 \% \mathrm{n}$-hexane ( $68^{\circ} \mathrm{C}$ boiling point), and $35 \%$ butan-1-ol/RNX95 $\left(118^{\circ} \mathrm{C}\right.$ and $250^{\circ} \mathrm{C}$ boiling points, respectively), one can conclude that the mass that remained added to the adsorbent surface was practically composed by active matter, particularly surfactant.

The importance of using a microemulsion, comparing with the use of a surfactant solution, is that the other components of the microemulsion system, although evaporated, help retaining the surfactant on the adsorbent surface after the drying process. Figure 4 shows a plot of sulfur adsorption capacity (q) versus the vermiculite modification drying time. 


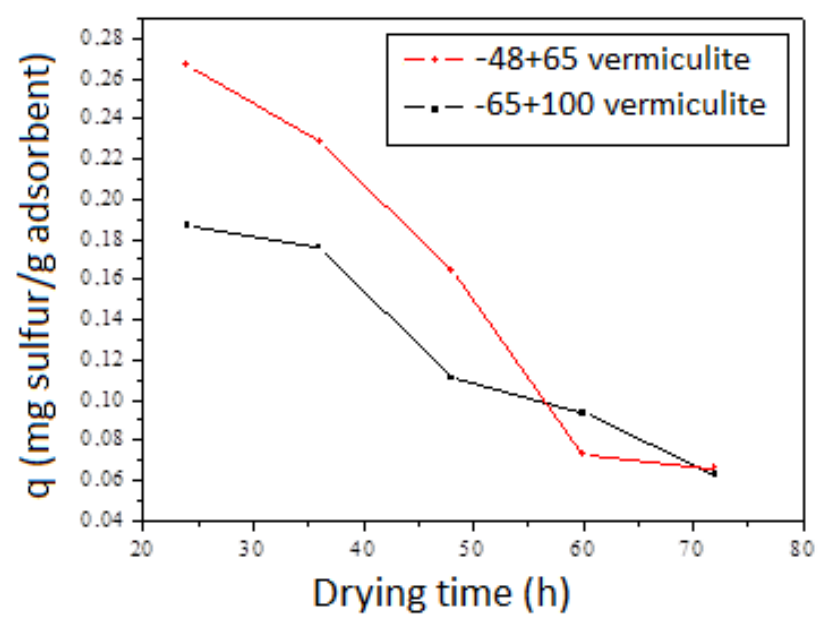

Figure 4. Adsorption capacity $\left(2 \mathrm{~h}\right.$ contact time, $\left.25^{\circ} \mathrm{C}\right)$ of vermiculite modified by microemulsion as a function of drying time (drying temperature: $60^{\circ} \mathrm{C}$ ).

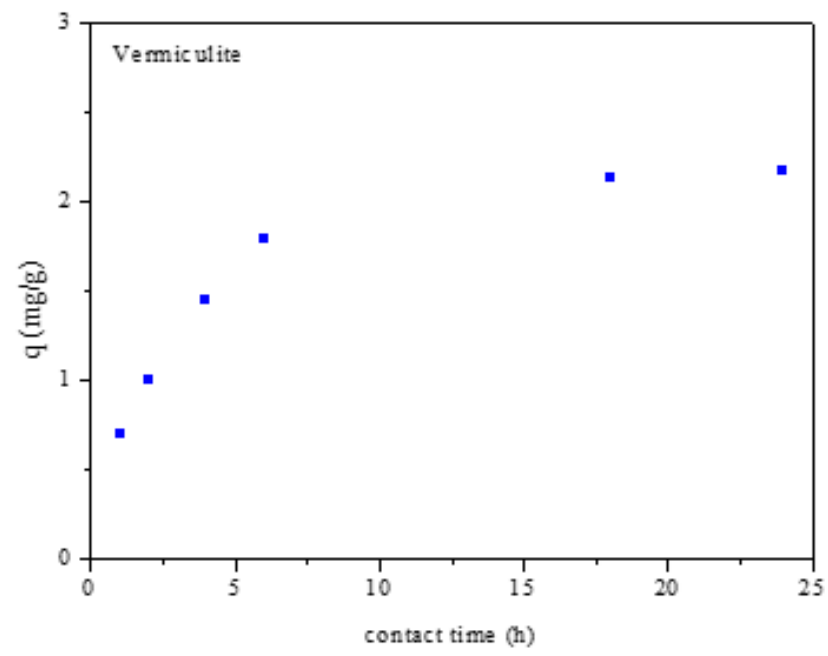

Figure 5 . Vermiculite adsorption capacity (q) as a function of contact time at $60^{\circ} \mathrm{C}$.

In Figure 4 one can observe that the sulfur adsorption capacity of the modified vermiculite decreases with time, indicating that the adsorbent loses its ability of capturing sulfur as the microemulsion's constituents evaporate. As previously explained, some constituents of the microemulsion system are important to retain the surfactant onto the surface of the adsorbent. Upon evaporation, a reduction in the surface area of the adsorbent is observed due to clogging of the adsorbent pores by the surfactant, which has high viscosity. The same behavior was observed for the two vermiculites evaluated. Based on these results, a 24-h drying time was established, and $-48+65$ vermiculite grain sizes were selected for subsequent adsorption experiments.

\subsection{Batch adsorption experiments for sulfur removal}

Figure 5 shows a plot to evaluate vermiculite adsorption capacity as a function of contact time, indicating the time when the system reaches an expected equilibrium. The microemulsion system used in this experiment, for adsorbent surface modification, was composed by $2 \%$ distilled water, $63 \% \mathrm{n}$-hexane, and 35\% butan-1-ol/RNX95. One can observe that the sulfur adsorption capacity increases gradually with increasing contact time, reaching a maximum value with $18 \mathrm{~h}$ of contact time.

Pseudo-first order (Lagergreen model, Eq. 2) and pseudo-second order (Eq. 3) mathematical models were applied to evaluate the kinetic mechanisms involved in the adsorption process: 


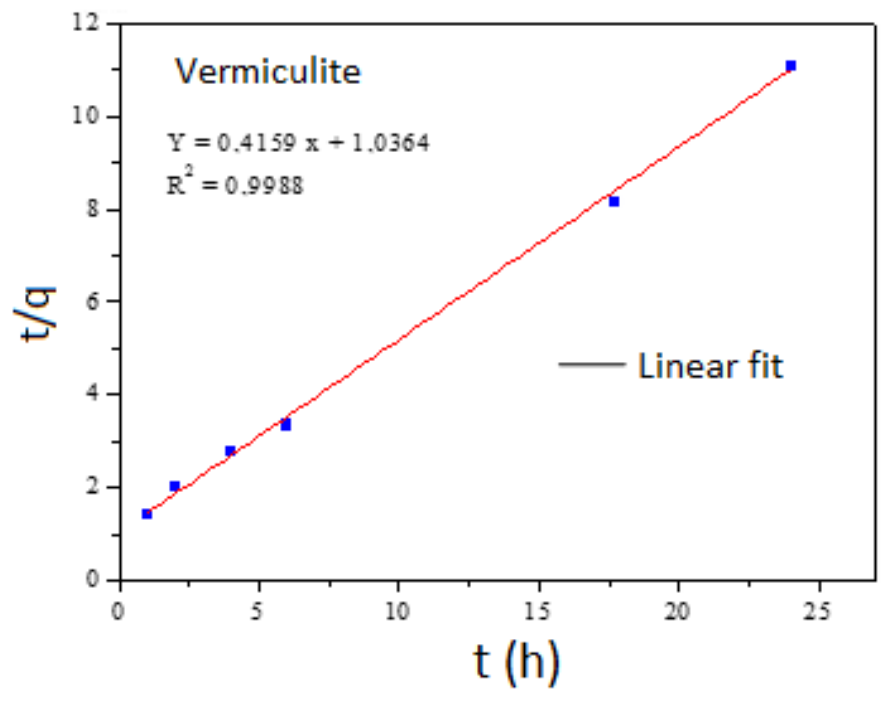

Figure 6. Vermiculite adsorption experimental data set adjusted using a linear fit of pseudo-second order kinetic model.

Table 7. Vermiculite adsorption kinetic parameters determined using the pseudo-second order kinetic model.

\begin{tabular}{ccccc}
\hline $\mathbf{q}_{\mathrm{E}(\mathrm{CALC})} \mathrm{mg} / \mathbf{g}$ & $\mathbf{q}_{\mathrm{E}(\mathrm{EXP})} \mathrm{mg} / \mathbf{g}$ & $\mathbf{k}_{\mathbf{2}}(\mathbf{m g} / \mathbf{g} \cdot \mathbf{m i n})$ & $\mathbf{R}^{2}$ & Error (\%) \\
\hline 2.4044 & 2.1727 & 0.1669 & 0.9988 & 9.63 \\
\hline
\end{tabular}

$$
\ln \frac{q_{E}-q_{1}}{q_{E}-q_{2}}=k_{1}\left(t_{2}-t_{1}\right)
$$

Where $q_{E}$ and $q_{t}$ are the adsorption capacity at equilibrium and at time $t$, respectively, and $k_{1}$ is the first-order kinetic adsorption constant. Results showed that the experimental data set deviated from the Lagergren model. Then, it was decided to apply a pseudo-second order model, according to Eq. 3:

$$
\frac{t}{q_{t}}=\frac{1}{k_{2} q_{E}^{2}}+\frac{t}{q_{E}}
$$

Where $q_{E}$ and $q_{t}$ are the adsorption capacities at equilibrium and at time $t$, respectively, and $k_{2}$ is the pseudo-second order kinetic adsorption constant. Figure 6 plots the experimental data fitted using the linear form of the pseudo-second order mathematical model. Table 7 shows the kinetic parameters. As one can verify, the experimental data were properly adjusted by the pseudo-second order kinetic adsorption model $\left(R^{2}=0.9988\right)$.

\subsection{Optimization of the adsorption parameters for microemulsion- modified vermiculite}

The adsorption parameters were optimized by applying a $2^{3}$ factorial experimental design. The results for adsorption capacity obtained in each experimental run are shown in Table 8.

Analyzing the results presented in Table 8 , one can observe that the highest values for sulfur adsorption capacity (q) were obtained for runs 2 and 4 , with the application of the same temperature $\left(60^{\circ} \mathrm{C}\right)$ and adsorbent grain size $(-48+65)$, varying only the $\mathrm{CaCl}_{2}$ solution concentration. It was also observed that the highest values for $q$ were reached when the maximum levels of temperature and $\mathrm{CaCl}_{2}$ solution concentration were employed, when comparing with experiments under the same conditions at the minimum level.

The results for adsorption capacity (q) were evaluated using a statistical software (Statistica ${ }^{\circledR}$, version 7.0) to determine the coefficients of the main effects and their interactions. Table 9 shows the effects obtained with the statistical treatment and one can observe that parameters temperature (1), $\mathrm{CaCl}_{2}$ solution concentration (2), interaction between temperature (1) and grain size (3), and interaction between $\mathrm{CaCl}_{2}$ solution concentration (2) and grain size (3), have a statistically significant effect for the $95 \%$ confidence interval $(p<0.05)$. It can also be observed that temperature (1), $\mathrm{CaCl}_{2}$ 
Table 8. Experimental conditions and results in a $2^{3}$ factorial design used for sulfur removal from diesel by adsorption ( $C_{0}=1233 \mathrm{ppm}, 18$-h contact time, 1:5 vermiculite:diesel ratio).

\begin{tabular}{ccccc}
\hline Run & $\mathbf{T} /{ }^{\circ} \mathbf{C}$ & $\mathbf{C a C l}_{2}$ solution (ppm) & Grain size (mesh) & $\mathbf{q}(\mathbf{m g} / \mathbf{g})$ \\
\hline 1 & 25 & 20 & $-48+65$ & 2.74 \\
2 & 60 & 20 & $-48+65$ & 4.28 \\
3 & 25 & 1500 & $-48+65$ & 3.46 \\
4 & 60 & 1500 & $-48+65$ & 4.24 \\
5 & 25 & 20 & $-65+100$ & 3.07 \\
6 & 60 & 20 & $-65+100$ & 2.90 \\
7 & 25 & 1500 & $-65+100$ & 4.03 \\
8 & 60 & 1500 & $-65+100$ & 4.09 \\
9 & 25 & 20 & $-48+65$ & 2.82 \\
10 & 60 & 20 & $-48+65$ & 3.89 \\
11 & 25 & 1500 & $-48+65$ & 3.81 \\
12 & 60 & 1500 & $-48+65$ & 3.94 \\
13 & 25 & 20 & $-65+100$ & 2.81 \\
14 & 60 & 20 & $-65+100$ & 3.17 \\
15 & 25 & 1500 & $-65+100$ & 3.75 \\
16 & 60 & 1500 & $-65+100$ & 3.88 \\
\hline
\end{tabular}

Table 9. Estimation of main effects and their interactions.

\begin{tabular}{lccc}
\hline \multicolumn{1}{c}{ Parameter } & Effect & Deviation & p \\
\hline Mean & 3.5548 & 0.0494 & 0.0000 \\
(1) Temperature & 0.4861 & 0.0989 & 0.0012 \\
(2) $\mathrm{CaCl}_{2}$ solution concentration & 0.6902 & 0.0989 & 0.0001 \\
(3) Grain size & -0.1866 & 0.0989 & 0.1036 \\
$1 * 2$ & -0.2142 & 0.0989 & 0.0621 \\
$1 * 3$ & -0.3910 & 0.0989 & 0.0042 \\
$2 * 3$ & 0.2605 & 0.0989 & 0.0299 \\
$1 * 2 * 3$ & 0.2125 & 0.0989 & 0.0639 \\
\hline
\end{tabular}

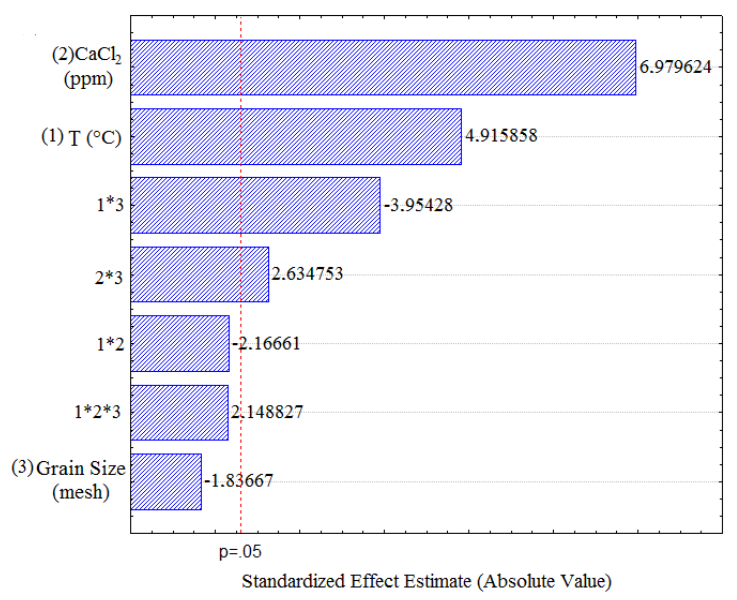

Figure 7. Pareto chart at the $95 \%$ confidence level showing the effect of the variables studied. solution concentration (2), and interaction between $\mathrm{CaCl}_{2}$ solution concentration (2) and grain size (3) affect the response positively. The interaction between temperature (1) and grain size (3) affect negatively the response. As for the grain size, both vermiculites evaluated in this work had similar sizes, therefore justifying the insignificance of this variable.

Figure 7 shows the Pareto chart for sulfur adsorption capacity by the modified vermiculite. In the Pareto chart, the significant effects are the ones that exceed the dashed line.

The linear regression coefficients that were significant in the adopted confidence interval (95\%) were used to obtain Eq. 4, a first-order mathematical model (linear) that describes the behavior of the adsorption capacity, where $T$ is 
Table 10. ANOVA for sulfur adsorption from diesel considering the adsorption capacity of vermiculite as response.

\begin{tabular}{lcccccc}
\hline \multicolumn{1}{c}{ Source } & Sun of squares & $\begin{array}{c}\text { Degrees of } \\
\text { freedom }\end{array}$ & $\begin{array}{c}\text { Mean sun of } \\
\text { squares }\end{array}$ & $\mathbf{F}_{\text {calculated }}$ & $\mathbf{R}^{\mathbf{2}}$ & $\mathbf{F}_{\text {table }}$ \\
\hline Regression & 4.0493 & 6 & 0.6749 & 12.31 & & 3.37 \\
Residual error & 0.4935 & 9 & 0.0548 & & 0.93 & 5.32 \\
Lack of fit & 0.1806 & 1 & 0.1806 & 4.62 & & \\
Pure error & 0.3129 & 8 & 0.0391 & & & \\
\hline
\end{tabular}

temperature, GS is grain size, and $\mathrm{AP}$ is concentration of $\mathrm{CaCl}_{2}$ solution.

$$
\begin{aligned}
& q=3.55_{( \pm 0.049)}+0.24[T]_{( \pm 0.049)}+ \\
& +0.34[A P]_{( \pm 0.049)}-0.19[T * G S]_{( \pm 0.049)}+ \\
& +0.13[A P * G S]_{( \pm 0.049)}
\end{aligned}
$$

Table 10 shows the analysis of variance (ANOVA) used to evaluate the significance of the coefficients. Analysis of Table 10 allows one to make many considerations about the studied process. To evaluate the statistical significance of the parameters of the model, the F-test was applied. The F-test establishes that models are significant when the $F$ value obtained from the regression is higher than the one given by the $F$ table $\left(F_{\text {calculated }} / F_{\text {table }}>1\right)$. Alternatively, if $F_{\text {calculated }} / F_{\text {table }}<1$, the model is considered as predictive. Comparing the values of $F$ calculated for the regression $\left(F_{\text {calculated }}=12.31\right)$ with the $F$ value given by the $F$ statistics table $(p=0.05)\left(F_{\text {table }}=3.37\right)$, one obtains $F_{\text {calculated }} / F_{\text {table }}=3.65$, which indicates that the model is significant. Similarly, the comparison between the $F$ value calculated for lack of fit $\left(F_{\text {calculated }}=4.62\right)$ with the value given by the F-statistics table $\left(F_{\text {table }}=5.33\right)$, with $F_{\text {calculated }} / F_{\text {table }}=0.87$, confirms that the linear model shown in Eq. 4 is predictive, obtaining 0.93 as coefficient of determination $\left(R^{2}\right)$. Figure 8 shows the behavior of the level curves.

In Figure 8, it is possible to observe the influence of temperature and $\mathrm{CaCl}_{2}$ solution concentration on the adsorption capacity. The increase in temperature towards the maximum level of the $\mathrm{CaCl}_{2}$ solution concentration (Figure $8(\mathrm{a})$ ) and the minimum level of grain size $(-48+65)$ (Figure $8(b)$ ) causes an increase in adsorption capacity. In Figure 8 (c) it is observed that the adsorption capacity increases towards the maximum level of $\mathrm{CaCl}_{2}$ solution concentration and the minimum level of grain size $(-48+65)$. According to the factorial planning, the best adsorption capacity will be achieved when using $60^{\circ} \mathrm{C}, 1550-p p m \mathrm{CaCl}_{2}$ solution, and $-48+65$ grain size.

\subsection{Adsorption isotherm}

Experiments for construction of adsorption isotherm $\left(q_{e}\right.$, in $\mathrm{mg} / \mathrm{g}$, versus $\mathrm{C}_{\mathrm{e}}$, in $\mathrm{mg} / \mathrm{mL}$ ) were performed using different amounts of adsorbent in contact with diesel, as shown in Figure 9.

In Figure 9 one can observe that the behavior displayed, in spite of not being clear enough to determine an isotherm, shows a tendency towards a type-III isotherm model, corresponding to an unfavorable absorption process that is characteristic of non-porous adsorbents.
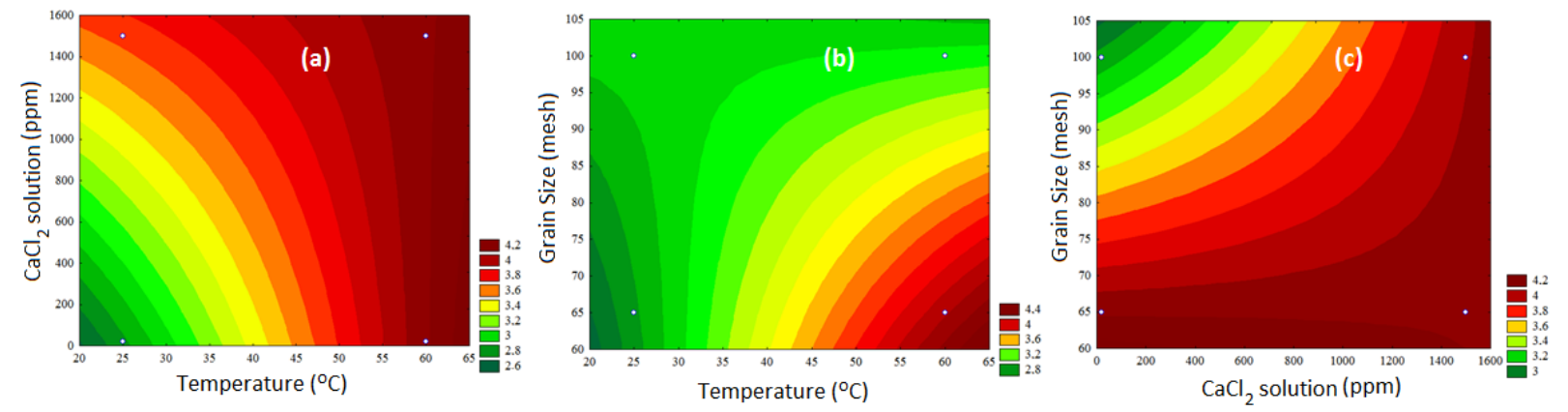

Figure 8. Evolution of the effects according to level curves: (a) Temperature versus $\mathrm{CaCl}_{2}$ solution concentration; (b) Temperature versus grain size; (c) $\mathrm{CaCl}_{2}$ solution concentration versus grain size. 


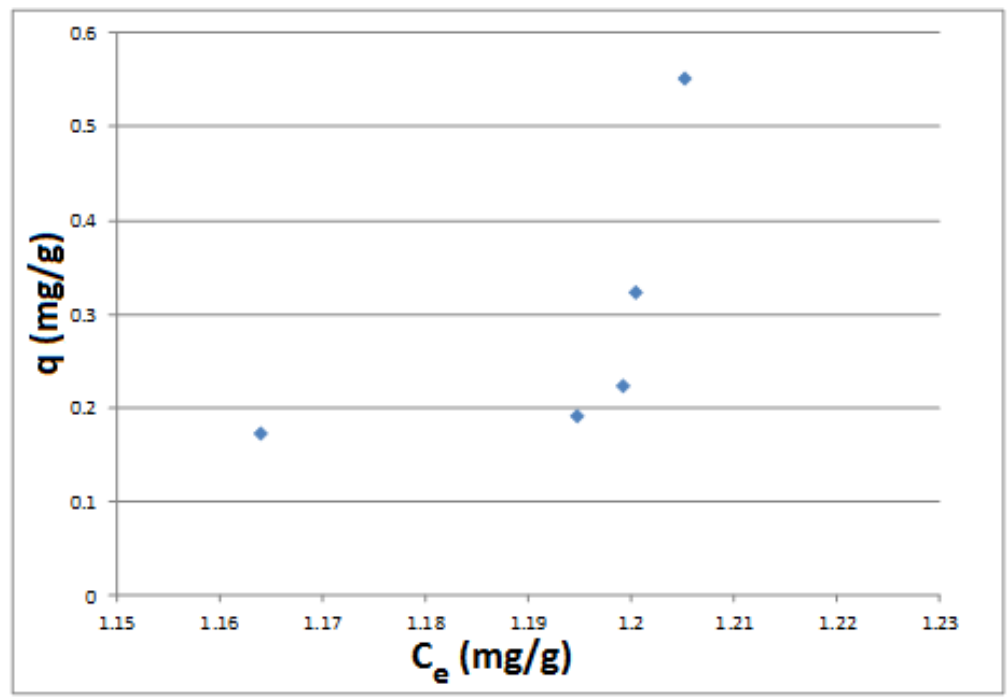

Figure 9. Adsorption isotherm for sulfur adsorption on vermiculite (24-h contact time;

$$
\left.\mathrm{C}_{0}=1233 \mathrm{ppm} ; \mathrm{T}=60^{\circ} \mathrm{C}\right) \text {. }
$$

\subsection{Comparative study: Modification of other adsorbents}

It was decided to evaluate bentonite and diatomite as adsorbents to compare the sulfur removal capacity with the results obtained by vermiculite. In these experiments, five microemulsion systems were tested in the modification of the surface of the selected clays, with different aqueous phase, including: distilled water, 20-ppm $\mathrm{CaCl}_{2}$ solution, 1500-ppm $\mathrm{CaCl}_{2}$ solution, 20-ppm $\mathrm{BaCl}_{2}$ solution and $1500-\mathrm{ppm} \mathrm{BaCl}_{2}$ solution. The assays were performed in batch $\left(60^{\circ} \mathrm{C}\right)$, with varied contact times. The results for bentonite, diatomite, and vermiculite are shown in Figures 10, 11, and 12 , respectively.

Figure 10 shows that the behavior of the adsorption capacity as a function of time is similar for all microemulsion-modified bentonites, with maximum adsorption capacity being reached after $18 \mathrm{~h}$ of contact time. A decrease in adsorption capacity is also observed with the use of saline solutions, with the microemulsion with distilled water presenting the best results.

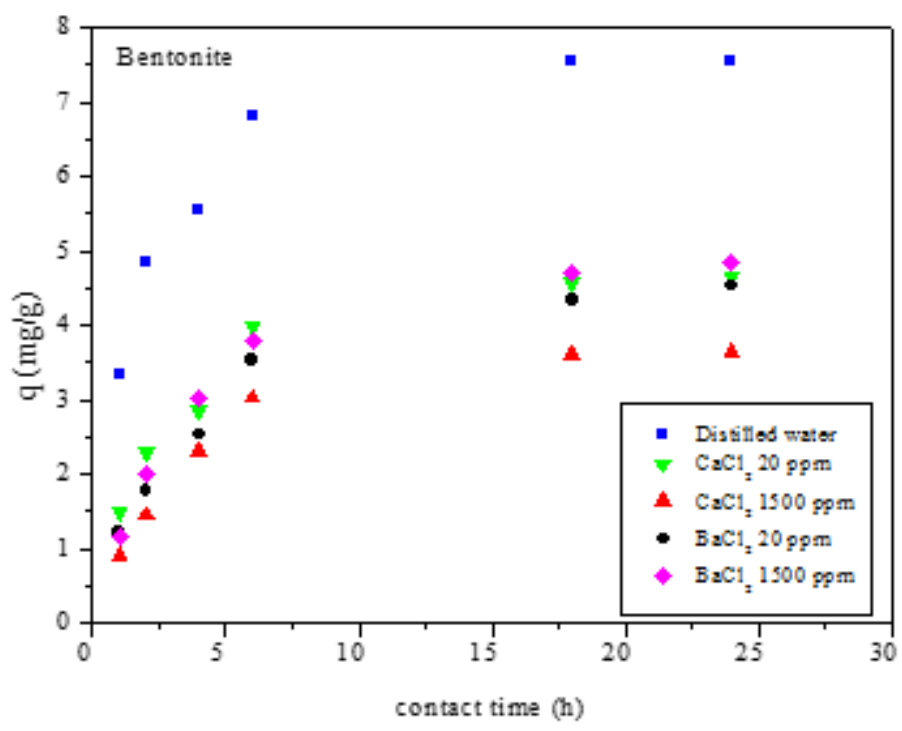

Figure 10. Adsorption capacity as a function of contact time for microemulsion-modified bentonite, at $60^{\circ} \mathrm{C}$. 


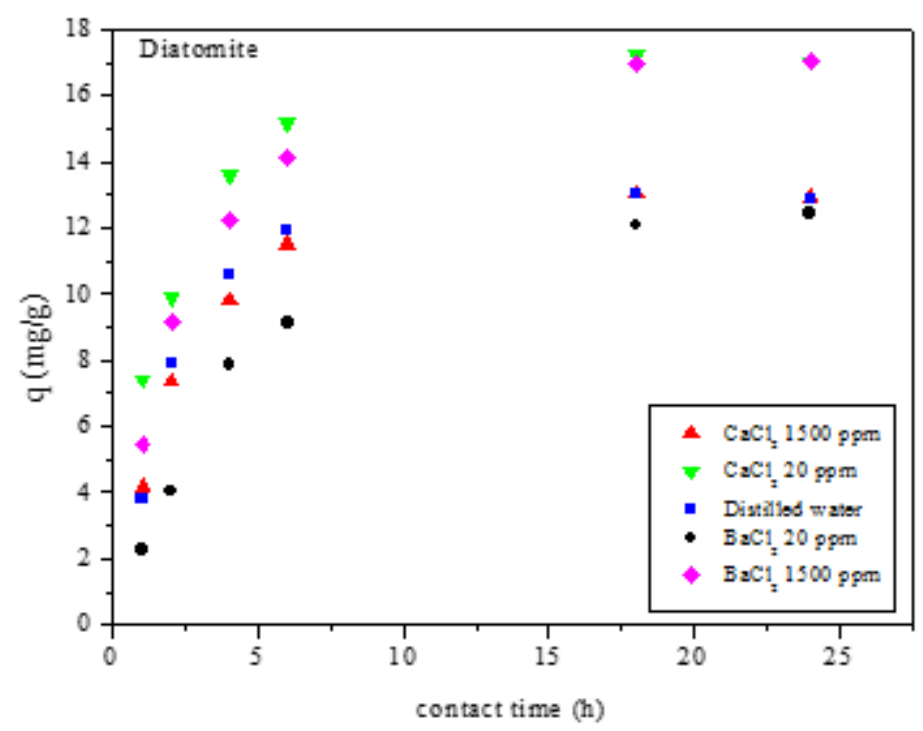

Figure 11. Adsorption capacity as a function of contact time for microemulsion-modified diatomite, at $60^{\circ} \mathrm{C}$.

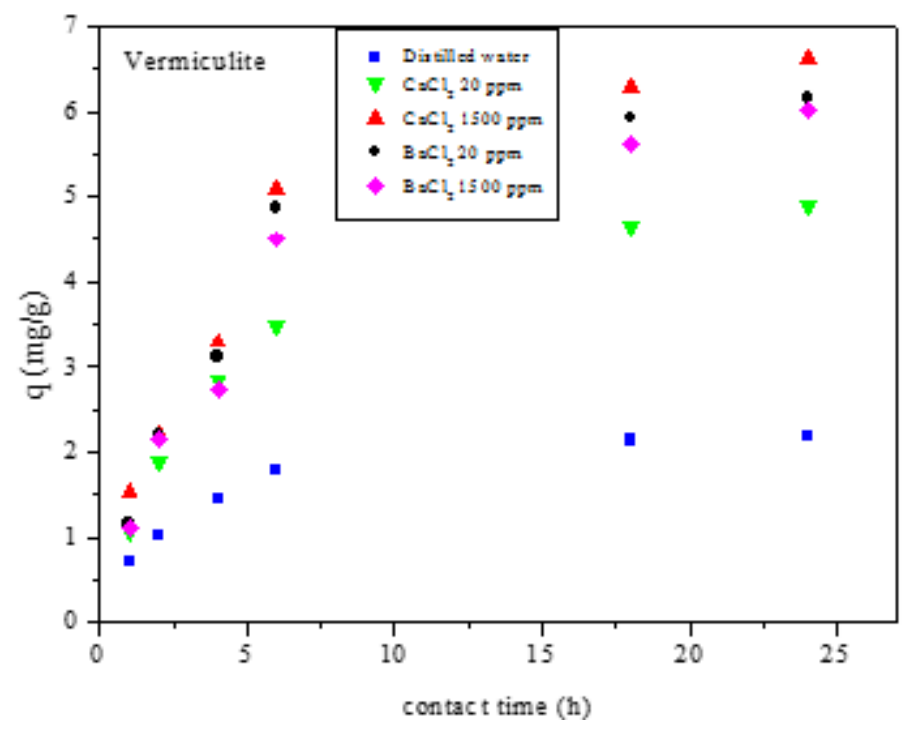

Figure 12. Adsorption capacity as a function of contact time for microemulsion-modified vermiculite, at $60^{\circ} \mathrm{C}$.

For diatomite, Figure 11 shows a very different behavior if compared with bentonite. The best results were obtained when using a $20-\mathrm{ppm} \mathrm{CaCl}_{2}$ solution. The lowest adsorption capacity values were observed with a $20-\mathrm{ppm} \mathrm{BaCl}$ solution as the aqueous phase of the microemulsion.

Figure 12 shows that the microemulsionmodified vermiculite using distilled water as aqueous phase presented the lowest adsorption capacities. It was observed that the addition of $1500-p p m \mathrm{CaCl}_{2}$ solution considerably increased the adsorption.
Diatomite presented the best results when using a microemulsion with a $20-\mathrm{ppm} \mathrm{CaCl}_{2}$ solution (17.04 mg of sulfur/g adsorbent). For bentonite, the best adsorption capacity was $7.53 \mathrm{mg}$ of sulfur/g adsorbent using a microemulsion system with distilled water. Finally, for vermiculite, the best result was obtained using a 1500-ppm $\mathrm{CaCl}_{2}$ solution, obtaining $6.63 \mathrm{mg}$ of sulfur/g adsorbent.

\subsection{Liquid-liquid extraction experiments}

In addition to adsorption, a liquid-liquid extraction procedure was performed using RNX95 as solvent in a crosscurrent two-stage process. The 


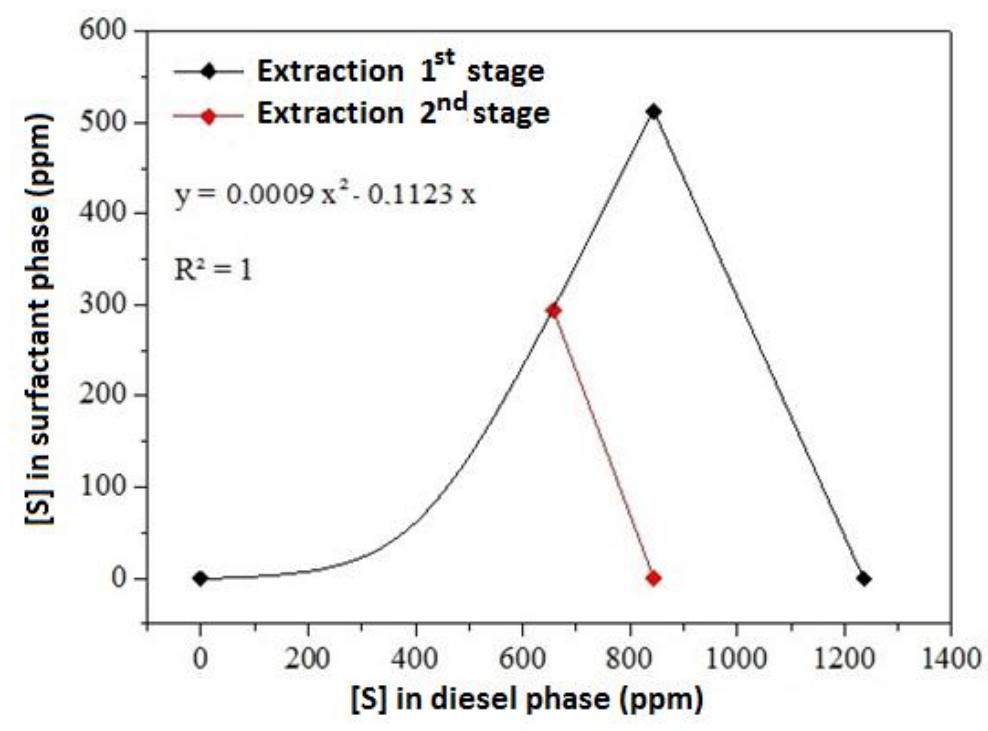

Figure 13. Liquid-liquid extraction for sulfur removal from diesel using a two-stage process (1:1 RNX95:diesel ratio, $\mathrm{t}_{\text {stirring }}=30 \mathrm{~min}, \mathrm{t}_{\text {centrifugation }}=5 \mathrm{~min}$, velocity $\left.=3800 \mathrm{rpm}, \mathrm{T}=25 \pm 2{ }^{\circ} \mathrm{C}\right)$.

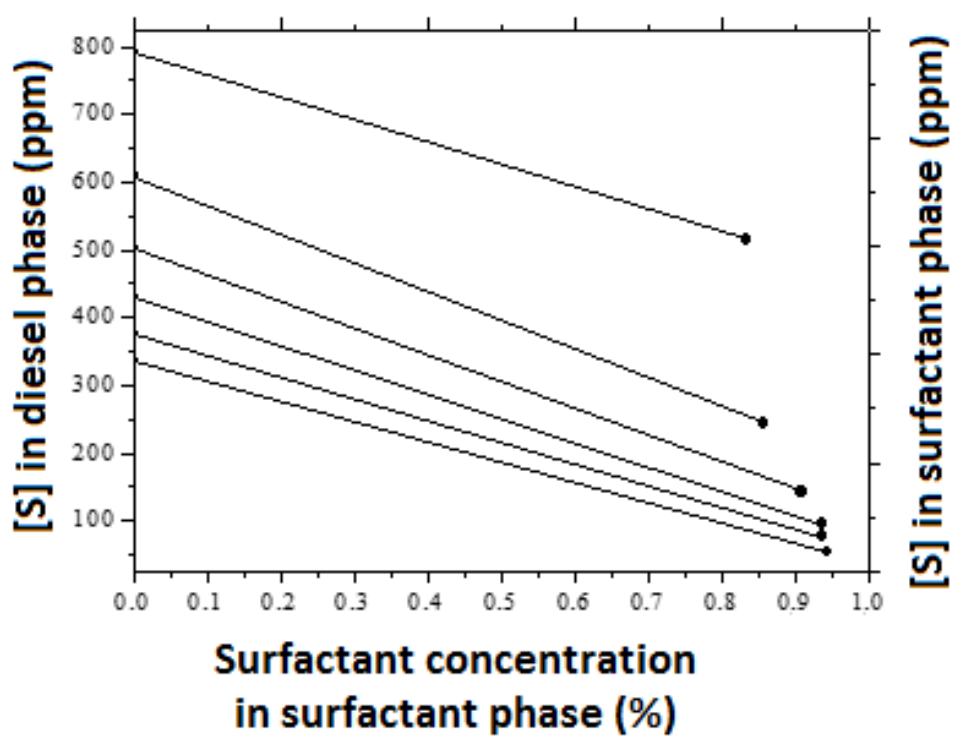

Figure 14. Liquid-liquid extraction for sulfur removal from diesel using a six-stage process (1:1 RNX95:diesel ratio, $\mathrm{t}_{\text {stirring }}=30 \mathrm{~min}, \mathrm{t}_{\text {centrifugation }}=5 \mathrm{~min}$, velocity $\left.=3800 \mathrm{rpm}, \mathrm{T}=25 \pm 2{ }^{\circ} \mathrm{C}\right)$.

process yielded a $46.8 \%$ sulfur extraction, as shown in Figure 13. In this figure one can observe that there is a tendency to form tie lines for sulfur equilibrium distribution between diesel and surfactant phases. This result led to the proposition of a liquid-liquid extraction process in six stages using the same surfactant as solvent, as shown in Figure 14.

Figure 14 presents the tie lines for sulfur concentration in the diesel-rich and surfactant-rich phases. The graph shows that a certain amount of diesel is dragged to the surfactant phase. The sulfur removal from liquid-liquid extractions, at the end of the sixth stage, was as high as $73.15 \%$. These results, in two and in six stages, show that RNX95 is efficient in removing sulfur from diesel fuel. However, it is important to consider the high cost of RNX95, justifying the research for alternative methods that use lower amounts of surfactant to remove contaminants from diesel. 


\section{CONCLUSIONS}

Two surfactants were investigated to remove sulfur from diesel in this research, an ionic and a nonionic one. Adsorption and liquid-liquid extraction processes were evaluated in sulfur removal. Microemulsion systems were applied to modify the surfaces of diatomite, bentonite, and vermiculite. The main conclusions of this work are:

- The nonionic surfactant, RNX95, proved to be more efficient in sulfur removal from diesel if compared to the cationic one (DDAC);

- Batch adsorption using a microemulsionmodified vermiculite showed that temperature and $\mathrm{CaCl}_{2}$ solution concentration were the most important parameters affecting sulfur removal;

- Microemulsion-modified diatomite presented the best results with removal of $17.04 \mathrm{mg}$ of sulfur/g adsorbent;

- For bentonite, the best adsorption capacity was $7.97 \mathrm{mg}$ of sulfur/g adsorbent, and for vermiculite the best result was $6.63 \mathrm{mg}$ of sulfur/g adsorbent;

- The liquid-liquid extraction process, in two and six stages, showed that RNX95 is efficient in removing sulfur from diesel fuel. However, the high cost of RNX95 justifies the research for alternative methods that use a lower amount of surfactant to remove contaminants from the diesel.

\section{REFERENCES}

Al Zubaidy, I. A. H.; Tarsh, F. B.; Darwish, N. N.; Majeed, B. S. S. A.; Sharafi, A. A.; Chacra, L. A. Adsorption Process of Sulfur Removal from Diesel Oil Using Sorbent Materials. Journal of Clean Energy Technologies, v. 1(1), p. 66-68, 2013. http://dx.doi.org/10.7763/JOCET.2013.V1.16

Almeida; R. K. S. Híbridos inorgânico-orgânicos de vermiculita e aminas alifáticas cíclicas e acíclicas - Adsorção e calorimetria. Dissertação de Mestrado. Programa de Pós-Graduação em Química, Universidade Federal da Paraíba, 2008. (in Portuguese)

Attwood, D.; Florence, A. T. Surfactant systems. London: $1^{\text {st }}$ Ed., Chapman and Hall, 1985.
Babich, I. V.; Moulijn, J. A. Science and technology of novel processes for deep desulphurization of oil refinery streams: a review. Fuel, v. 82, p. 607-631, 2003. http://dx.doi.org/10.1016/S0016-2361(02)00324-1

Braun, S.; Appel, L. G.; Schmal, M. A poluição gerada por máquinas de combustão interna movidas a diesel - A questão dos particulados. Estratégias atuais para a redução e controle das emissões e tendências futuras. Quim. Nova, v. $27(3)$, p. 472-482, 2003. (in Portuguese) http://dx.doi.org/10.1590/S0100-40422004000300018

Clause, M.; Heil, J.; Zradba, A.; NicolasMorgantine, L. J. Comp. Esp. Deterg: v. 16, p. 497, 1985. In: Clause, M.; Nicolas-Morgantine, L.; Zradba, A. Touraud, D. Microemulsion Systems: Water / Ionic Surfactant /Alkanol / Hidrocarbon Systems: Influence of Certain Constitution and Composition Parameters Upon the Realms-of-Existence and Transport Properties of Microemulsion Type Media. New York: Marcel Dekker, Inc, 1987.

del Nunzio, M. J. Tensoativos e suas aplicações práticas. Aerosol \& Cosméticos, v. 2(10), p. 14-22, 1980.

Drăgan, G.; Butucea, D. O. The equilibrium of adsorption processes of sulphur dioxide on zeolites - U.P.B. Science Bulletin, Series B, v. 74(3), p. 61-68, 2012.

Gomide, R. Operações Unitárias. 1a Ed., São Paulo: Reynaldo Gomide, v. 4, p. 311-331, 1988 (in Portuguese)

Grim, R. E. Clay mineralogy. $2^{\text {nd }}$ Ed. New York: McGraw-Hill, 1968.

Hernández-Maldonado, A. J.; Yang, R. T. Desulfurization of Diesel Fuels via $\pi$-Complexation with Nickel (II) - Exchanged X- and Y-Zeolites. Industrial and Engineering Chemistry Research. v. 43(4) p. 1081-1089, 2004. http://dx.doi.org/10.1021/ie034206v

Izumi, Y.; Ohshiro, T.; Ogino, H. Selective desulfurization of dibenzothiophene by Rhodococcus erythropolis D-1. Applied and Environmental Microbiology, v. 60(1), p. 23-226, 1994. 
Knudsen, K. G., Cooper, B. H.; Topsøe, H. Catalyst and process technologies for ultra low sulfur diesel. Applied Catalysis A: General, v. 189(2), p. 205-215, 1999. http://dx.doi.org/10.1016/50926-860X(99)00277-X

Mochida, I.; Sakanishi, K.; Ma, X.; Nagao, S.; Isoda, T. Deep hydrodesulphurization of diesel fuel: Design of reaction process and catalysts. Catalysis Today, v. 29, p.185-189, 1996.

http://dx.doi.org/10.1016/0920-5861(95)00262-6

Myers, J. B. Vermiculite. Industrial Minerals and Rocks: Non-metallics other than Fuels. New York: Gillson, J. L. (Editor), $3^{\text {rd }}$ edition, The American Institute of Mining, Metallurgical and Petroleum Engineers (AIME), p. 889-895, 1960.

Padilla-Ortega, E.; Levya-Ramos, R.; MendozaBarron, J. Role of electrostatic interactions in the adsorption of cadmium (II) from aqueous solution onto vermiculite. Applied Clay Science, p. 88-89, 2014.

Prince, L. M. Microemulsion: Theory and Practice. New York: Academic Press, 1977.

Rau, E. Vermiculite. SME Mineral Processing Handbook. New York: Weiss, N. L. (Editor), AIME, p. 21-29, 1985.

Santos, F. K. G; Barros NETO, E. L. Moura, M. C. P. A.; Dantas, T. N. C.; Dantas Neto, A. A. Molecular behavoir of ionic and nonionic surfactants in saline medium. Colloids and Surface A: Physicochemical and Engineering Aspects. v. 333, p. 156-162, 2009. http://dx.doi.org/10.1016/i.colsurfa.2008.09.040

Santos, P. S. Ciência e Tecnologia de Argilas. São Paulo: Editora E. Blucher, 2a Ed., v.3, 1989 (in Portuguese)

Sari, A.; Tuzen, M.; Adsorption of silver from aqueous solution onto raw vermiculite and manganese oxide-modified vermiculite. Microporous and Mesoporouse Materials. v. 170, p. 155-163, 2013.

http://dx.doi.org/10.1016/j.micromeso.2012.12.004
Scherer, R. P., Malvesti, Á. L., Pergher, S. B. C.; De Souza, W. F. Estudo de adsorção de compostos sulfurados utilizando um diesel comercial dopado com benzotiofeno e dibenzotiofeno, Quím. Nova, v.32 (1), p. 34-37, São Paulo, 2009. (in Portuguese)

Scriven, L. E. Equilibrium bicontinous estructure, Nature, v. 263, p.123-125, 1976, in: Robb, I. D. Microemulsion. $1^{\text {st }}$ Ed., New York: Plenum Press, 1982.

Thomas, J. E. Fundamentos de Engenharia de Petróleo. Rio de Janeiro: Interciencia: Petrobrás, 2001. (in Portuguese)

Turan, N. G.; Ozgonenel, O. Optimizing copper ions removal from industrial leachate by explored vermiculite - A comparative analysis. Journal of the Taiwan Institute of Chemical Engineers. v.44, p 895903, 2013.

http://dx.doi.org/10.1016/i.jtice.2013.03.004

Valdiviezo, E. V.; Souza, M. M.; Leitão, T. J. V.; Guerara, E. A. Caracterização e esfoliação térmica de vermiculitas dos estados da Paraíba e do Piauí. Anais do XIX Encontro Nacional de Tratamento de Minérios e Metalurgia Extrativa, v.1, p. 562-569, Recife, 2002. (in Portuguese)

Winsor, P.A. Trans Faraday Soc. v. 44, p. 376-398, 1948 In: Dantas, T. N. C; Dantas Neto, A. A; Rossi, C. G. F. T.; Gomes, D. A. A.; Gurgel, A. Use of Microemulsion System in the Solubilization of Petroleum Heavy Fractions for the Prevention of Oil Sludge Waste Formation. Energy \& Fuels, v. 24, p 2312-2319, 2009. 